\title{
A PROJECT MANAGEMENT APPROACH TO E-HEALTH MARKETING CAMPAIGNS
}

\author{
Artur Bjelica ${ }^{1,2}$, Vuk Rakočević ${ }^{3}$, Branka Rodić ${ }^{4}$ \\ Radmila Janičić ${ }^{4}$, Marina Jovanović Milenkovićc ${ }^{4}$ \\ ${ }^{1}$ Faculty of Medicine, University of Novi Sad, Serbia \\ ${ }^{2}$ Clinical Center of Vojvodina, Department of Obstetrics and Gynecology, Novi Sad, Serbia \\ ${ }^{3}$ Embassy of Montenegro in the Republic of Serbia, Belgrade \\ ${ }^{4}$ Faculty of Organizational Sciences, University of Belgrade, Serbia
}

\begin{abstract}
The objective of the study is the designing of e-health marketing campaigns using the principles of project management, with the aim to ensure a successful outcome of social marketing goals. The analysis encompasses certain specific features of social marketing and particular steps in designing social marketing campaigns in e-health. Based on the analyzed concepts, a social marketing campaign is designed for promotion of reproductive health care among women in the Republic of Serbia. The proposed campaign relies on extensive usage of ehealth services. It is pointed out that an appropriate project management is needed in order to ensure a successful outcome of the campaign and the changes resulting in the behavior of the target population.
\end{abstract}

Key words: Social marketing, e-health, campaign management.

\section{INTRODUCTION}

Promotion and prevention of reproductive health is of great importance for a general health and a prerequisite for human development (Cumming, Morris, Simpson, French, Kahana, Luciano, \& Molik, 2016). Reproductive health is involved in national healthcare programs in the majority of countries. There are numerous modalities that can be used to implement promotion and prevention in reproductive health programs. These modalities are constantly being investigated in order to meet reproductive health standards. The aim is to perceive and assess the reproductive health in population, the opportunities for promotion of reproductive health, and also to find out the potential methods for their implementation.

The importance and potential of social marketing strategies in reproductive health promotion and prevention have been recognized by numerous international studies (Dooley, Jones, \& Desmar, 2009; Firestone, Rowe, Modi, \& Sievers, 2017). Also, the significance and implications of social media in marketing were examined (Alves, Fernandes, \& Raposo, 2016).

In this paper, the possibilities offered by marketing principles and social marketing strategies are analyzed. The goal of the work is to promote awareness of the importance of reproductive health of women, and the impact on the change in behavior if women in the Republic of Serbia. To achieve this goal, modern technologies and tools such as ehealth services promoted through social media, will be used.

\section{LITERATURE REVIEW}

\subsection{Social marketing in e-health}

Marketing in healthcare is an important segment for the maintenance and further development of healthcare system, in addition to medical knowledge and modern health equipment. Marketing in healthcare encompasses a range of activities - from market research to profitability control, which must be applied at all levels of healthcare in order to satisfy the needs of healthcare users and achieve appropriate benefit (profit, good 
reputation, employee satisfaction). The goals of marketing in healthcare are (Doug, 2006) (Eckrich, \& Schlesinger, 2011):

- more efficient meeting the needs of the health services customers and valuable business,

- raising the level of healthcare quality and the quality of life,

- vertical and horizontal connection of the participants in the healthcare system in order to provide preventive programs,

- determining the priorities of the development of the healthcare system,

- rationalization of bussines,

- more economical use of available resources.

In medicine area, marketing is focused on:

- improvement of the provision of healthcare services - it is necessary that the healthcare service providers perceive the needs of the healthcare users; healthcare services must be available 24 hours at the place where the users need them, and at the price that the users are willing to pay. The ultimate goal of marketing is to satisfy the needs of users and society, as well as the implementation of strategies that will contribute to a healthcare institution maintenance in the market and profitable business of the institution,

- the user or customer, in terms of changing behaviors and lifestyles achieved through the application of social marketing strategies.

By definition, social marketing is a process in which the concept and techniques of marketing are applied to social issues and causes, and not to products and services. Thus, people are being trained to take responsibility for their own health and wellbeing. It is a process through which, new or innovative, ways of solving health and social problems are proposed, in order to benefit the target population or the society as a whole.

Social marketing is trying to influence the way people think, and is considered as a comprehensive strategy for achieving the social change on a wide scale. In order for changes to occur, it is necessary to identify specific consumer groups (that requires the use of all community data), use different techniques and approaches, and engage health workers and many other experts. The success of social marketing is measured through the accepted postures and behaviors that came out from its activities.

Through social marketing, positive changes are made, and harmful habits are modified or abandoned. At the same time, this assumes maintenance of certain desirable behavior in individuals, that we usually call the target population (Truong, 2014). The concept of social marketing, created by ideas emerging from commercial marketing combined with other social science disciplines, proved to be successful tool for influencing people's behavior in a sustainable and economical way (Kotler, \& Zaltman, 1971; Dibb, \& Carrigan, 2013; Andreasen, 1995).

Social marketing strives to develop and integrate its concepts with other approaches. The aim of such integration is to influence the behavior of individuals and communities for greater social welfare. The practice of social marketing is guided by ethical principles. It strives to integrate research, best practice, theory, audience and partnership to deliver informative and segmented social change programs. Those programs are effective, efficient, fair, unbiased, and sustainable (iSMA, ESMA, \& AASM, 2013).

In other words, social marketing means the use of principles and techniques of marketing in order to influence the target population to voluntarily accept, reject, change or abandon behavior and all for the benefit of the individual, community or society as a whole (Kotler, Roberto, \& Lee, 2008). The principles and techniques of social marketing can be used for the benefit of society and selected, targeted populations in many ways. Over the years, during development of social marketing, it has been focused on four areas: health promotion, injury prevention, environmental protection, and community mobilization (Cheng, Kotler, \& Lee, 2011).

Social marketing has a very important role in public healthcare, where it is used in solving 
public health issues (Ling, Franklin, Lindsteadt, \& Gearon, 1992). There are numerous health areas where social marketing is used: reducing risky behavior in HIV infections, preventing various chronic diseases, preventing smoking in adolescents, campaigning against child abuse, increasing the efficiency of public health services, promoting family planning, breastfeeding, healthy eating and healthy lifestyle, promotion of physical activity, etc (Cheng, et al., 2011).

Technological progress, adoption of new technologies and legislation, determine the direction in which the social marketing will be used. Globalization and information availability have a very important role in the development of social marketing (Cheng, et al., 2011). Besides, the development of social media provides enormous opportunities for the application of social marketing. However, user's data, disposed by Google and Facebook, are not being used to their full potential due to privacy and data protection law on the Internet (European Union Agency for Fundamental Rights, 2018).

There are a few basic steps in implementing a social marketing campaign: choosing a target population that will benefit from a particular change in behavior of target group, analysis of that population, and, based on the previous selection of methods and tools that suit best the target population. There are numerous tools and their number increase due to technological development and emergence of the Internet, social networks, and smartphones. One should also mention traditional tools, like: leaflets, brochures, billboards, radio, articles in magazines, and ads in newspapers. More popular tools are: the use of television for commercials, ads in shows, movies, music spots, etc., use of the Internet as well as the social networks (Facebook, Instagram, etc).

Public health issues or subjects can be mentioned or discussed in movies, or displayed through brochure, leaflet or billboard in a movie scene. Besides, cartoons can be used to educate and learn the desirable behavior in children population. Music presents a powerful social marketing tool because it causes certain emotions in people. Some music tracks can be specially written for a particular campaign. Music concerts are often organized with the aim of increasing the awareness of some public health issue, promoting behavioral change, or promoting public health activity donation.

The Internet can be used to create a web site that publishes and informs the target population, provides access to campaign materials, and means to get in touch with those who conduct the campaign. Also, online advertising is a very convenient and powerful tool for reaching the target population as targeted ads are set up.

A model of the effects of social marketing is shown in figure 1 .

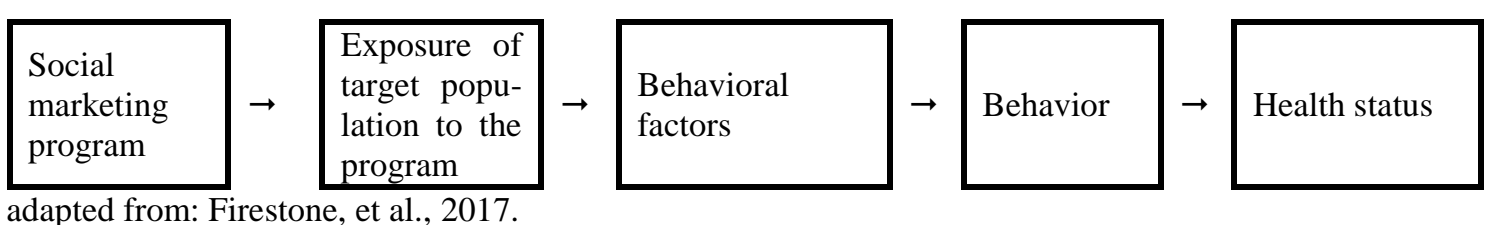

Figure 1: A model of social marketing effects

\subsection{Designing social marketing campaigns}

In the area of social marketing, the organizations and institutions working on primary prevention, use two types of activities:

- programs,

- campaigns.
The program presents a long-term coordinated activity, designed to accomplish an organization's mission and it can involve one or more specific campaigns. The campaign is short-term, and its aim is to achieve certain results in a short time frame. Campaigns and programs have their own strategy, plans and tactics (Todorović, n.d.). 
The most successful social-marketing campaigns can be anatomized in 10 steps (SAMSHA, 2017).

1. Defining of the target population - this step should be maximally specific and should find out as much as possible about specific population; try to imagine individuals in the group, understand their tendency, attitudes, feelings, values, motivation and cultural habits. All these factors influence one's behavior.

2. Identify evaluation measurement - the evaluation has a major role in prevention; develop an evaluation strategy even during the planning process; think about evaluation issues as well as methods of collecting necessary information.

3. Identify channels - it is necessary to think about the ways of communication or sending messages; one of the options is sending messages direct to the target population via television, radio, advertisements, articles, interviews, or billboards; another way is to indirectly send messages through mediators. Mediators can be people who work with the target population - trainers, teachers, counselors, people who are respected and valued, and different organizations.

4. Identifying the benefits - should be thought from the perspective of the target population; short-term and long-term benefits are distinguished.

5. Identify an obstacle - obstacles can prevent members of the target population from adopting the given behavior; messages must be strong enough to overcome obstacles.

6. Identify messages - a very significant step; try to emphasize positive behavior rather than negative consequences; it is important to determine the tone and style of the message - whether it is informative, emotional, with a dose of humor.

7. Testing and adjusting - it is important to pre-test the message; it is the best to present several samples to a focus group that is representative of the target population and record their reactions and impressions; based on this, a message can be fine-tuned regarding comprehensibility, power to attract attention, relevance and sensitivity.
8. Data collection - collect data if the message had an effect.

9. Modifying a campaign based on data sometimes small changes during the campaign have a great effect.

10. Writing an evaluation report.

Kotler, et al., (2008) define eight steps of social marketing:

1. Situation analysis

2. Selecting target population

3. Define general and specific goals

4. Analyzing target groups and competition

5. Design marketing strategies

6. Evaluation plans

7. Budgeting

8. Finalizing phase.

This approach will be used for designing the social marketing campaign in this paper. In addition, the principles of agile project management can contribute to achieving effectively the expected campaign result.

\section{DESIGNING A SOCIAL MARKETING CAMPAIGN FOR PROMOTION OF REPRODUCTIVE HEALTH CARE USING E-HEALTH SERVICES}

\subsection{Project requirements}

The campaign is titled "Reproductive health? Be informed, be aware! React!". It is designed to be conducted on the territory of the Republic of Serbia. The campaign itself is quite complex as it includes contents from different sources and harnessing mobile applications and services as well. The main goal is to improve the level of reproductive health and awareness of importance of this issue. The analysis of the target population points out a huge need for this kind of campaign. Further, many women in Serbia use Internet and social media for getting information regarding health. Accordingly, the main part of the campaign is the app that could be downloaded as a mobile app or used as a web application.

The application contains information related to reproductive health (importance of reproductive health, certain diseases of reproductive tract within female population, 
sexually transmitted diseases, cancer and breast cancer, unwanted pregnancy, contraception, sterility, etc.). Depending on the age of a user, the application provides appropriate content that is focused on typical problems in that age. The application will be promoted via different channels: social networks (Facebook and Instagram), TV and newspaper advertisement, influencers. The main idea is that the application provides high quality content about reproductive health, typical problems and methods of prevention. Further, the app should provide a Q\&A section.

\subsection{Project plan}

The phases in the campaign management were based on the directions from Kotler et al. (Kotler, et al., 2008), as shown in Table 1.

Table 1: Campaign plan

\begin{tabular}{|c|c|c|}
\hline PHASE & SUBPHASE & DESCRIPTION \\
\hline \multirow[t]{7}{*}{$\begin{array}{l}\text { 1. SITUATION } \\
\text { ANALYSIS }\end{array}$} & $\begin{array}{l}\text { Which social issue the } \\
\text { campaign deals with? }\end{array}$ & - Promotion of reproductive health in the Republic of Serbia \\
\hline & $\begin{array}{l}\text { 1.2 What is the focus of } \\
\text { the campaign? }\end{array}$ & $\begin{array}{l}\text { - Increase awareness of importance of reproductive health in } \\
\text { women population in the Republic of Serbia using e-health } \\
\text { services (both web application and mobile phone app) } \\
\text { - There is a high level of readiness for using Internet, cell } \\
\text { phones and social networks for gathering information } \\
\text { related to health. Further, non-adequate care about } \\
\text { reproductive health has been identified (rare medical } \\
\text { checks, no contraception, unwanted pregnancy, etc.) } \\
\text { (Bjelica, 2018) }\end{array}$ \\
\hline & $\begin{array}{l}\text { 1.3 What is the purpose } \\
\text { of the campaign, what } \\
\text { impact is expected? }\end{array}$ & $\begin{array}{l}\text { - Improving the level of reproductive health of women in } \\
\text { the Republic of Serbia. Positive impact is reflected in a } \\
\text { greater awareness of the importance of reproductive } \\
\text { health, prevention of illness in women, increased use of } \\
\text { contraception, and reduced number of unwanted } \\
\text { pregnancies. }\end{array}$ \\
\hline & $\begin{array}{l}\text { 1.4 Which aspects will be } \\
\text { improved? }\end{array}$ & $\begin{array}{l}\text { - Currently, there are several strategies and programs related } \\
\text { to productive health: National strategy for young people, } \\
\text { National program for prevention of cervical cancer, } \\
\text { National program for breast cancer, as well as the recently- } \\
\text { launched National program for saving and improving } \\
\text { sexual and reproductive health of citizens of the Republic } \\
\text { of Serbia. The campaign should enhance the efficiency } \\
\text { and outcomes of these strategies. }\end{array}$ \\
\hline & $\begin{array}{l}\text { 1.5 Which weaknesses } \\
\text { will be solved? }\end{array}$ & $\begin{array}{l}\text { - The resistance toward using contraception and } \\
\text { insufficiency of information disseminated about } \\
\text { importance of reproductive health. }\end{array}$ \\
\hline & $\begin{array}{l}\text { 1.6 What external } \\
\text { impacts will the } \\
\text { project have? }\end{array}$ & $\begin{array}{l}\text { - Thanks to the use of social networks, this should have an } \\
\text { impact on the whole population and various groups of } \\
\text { stakeholders. }\end{array}$ \\
\hline & $\begin{array}{l}1.7 \text { What important } \\
\text { aspects of previous } \\
\text { studies will the } \\
\text { project address? }\end{array}$ & $\begin{array}{l}\text { - Previous experiences in the Republic of Serbia point to the } \\
\text { existence of some parents' resistance to the sexual } \\
\text { education of their teenage children. As a reason, it is most } \\
\text { often stated that such education encourages sexual } \\
\text { intercourse. Also, previous campaigns on the use of } \\
\text { contraception have been met with significant resistance to } \\
\text { the use of hormonal contraceptives under the explanation } \\
\text { that this is unnatural and has many consequences for the } \\
\text { health of women. Activities within family planning in } \\
\text { Serbia are at a very low level (Government of the Republic } \\
\text { of Serbia, 2017). }\end{array}$ \\
\hline
\end{tabular}




\begin{tabular}{|c|c|c|}
\hline $\begin{array}{l}\text { 2. TARGET } \\
\text { GROUPS }\end{array}$ & & $\begin{array}{l}\text { - The target group for the campaign includes women in } \\
\text { reproductive age, that is from } 15 \text { to } 50 \text { years. According to } \\
\text { the estimations from December } 2017 \text {. there are } 1.577 .323 \\
\text { women in this age (Statistical Office Republic of Serbia, } \\
\text { 2017). It is estimated that the reproductive health of } \\
\text { women in the Republic of Serbia is not at an adequate } \\
\text { level. According to (HPV Information Center, 2017), } \\
\text { Serbia occupies one of the leading places in Europe for the } \\
\text { number of women suffering from cervical cancer. }\end{array}$ \\
\hline \multirow[t]{4}{*}{$\begin{array}{l}\text { 3. GENERAL } \\
\text { AND } \\
\text { SPECIFIC } \\
\text { GOALS }\end{array}$} & $\begin{array}{l}3.1 \text { Behavior }- \text { what do } \\
\text { you want to make impact } \\
\text { on? }\end{array}$ & $\begin{array}{l}\text { - In the first place, increasing the level of awareness about } \\
\text { the importance of prevention in reproductive health } \\
\text { - Encouraging women in the reproductive period to go on a } \\
\text { regular basis to a gynecologist, } \\
\text { - Encourage women to regularly check their breasts, } \\
\text { - Increased use of contraception, } \\
\text { - Responsible reproductive behavior. }\end{array}$ \\
\hline & $\begin{array}{l}3.2 \text { Knowledge - Should } \\
\text { the target group know } \\
\text { something new in order to } \\
\text { achieve desired behavior? }\end{array}$ & $\begin{array}{l}\text { - It is necessary for the target group to have more } \\
\text { information on the importance of reproductive health and } \\
\text { preventive activities in the field of reproductive health. }\end{array}$ \\
\hline & $\begin{array}{l}3.3 \text { Belief - Does the } \\
\text { target group, in order to } \\
\text { behave in the desired way, } \\
\text { have something to believe } \\
\text { in? }\end{array}$ & $\begin{array}{l}\text { - Increased awareness of certain reproductive health issues } \\
\text { leads to activities that can prevent certain diseases and } \\
\text { problems from the domain of reproductive health, } \\
\text { - Preventive activities can improve their own reproductive } \\
\text { health, } \\
\text { - Preventive examinations allow early diagnosis and rapid, } \\
\text { effective treatment, } \\
\text { - The use of contraception is safe. }\end{array}$ \\
\hline & $\begin{array}{l}\text { 3.4. What are the specific } \\
\text { goals that could be } \\
\text { measured? }\end{array}$ & $\begin{array}{l}\text { - Specific targets include the number of downloaded } \\
\text { applications, the number of visits to the gynecologist, the } \\
\text { number of early cervical and breast cervical disorders, the } \\
\text { number of pregnancy breaks, etc. }\end{array}$ \\
\hline \multirow[t]{5}{*}{$\begin{array}{l}\text { 4. TARGET } \\
\text { GROUPS } \\
\text { AND } \\
\text { COMPETITIO } \\
\text { N ANALYSIS } \\
\end{array}$} & 4.1 Current beahvior & $\begin{array}{l}\text { - The conducted survey suggests that the target population is } \\
\text { not concerned enough about their reproductive health. } \\
\text { Their knowledge is based on the experience gained } \\
\text { through the Internet and social networks.(Bjelica, 2018) }\end{array}$ \\
\hline & 4.2 What they know? & $\begin{array}{l}\text { - It could be realized that the target group women } \\
\text { understand to some extent the importance of preventive } \\
\text { activities in preserving their own reproductive health. }\end{array}$ \\
\hline & 4.3 What they believe in? & $\begin{array}{l}\text { - Previous research carried out in Serbia indicated the } \\
\text { existence of an illusion about the control of fertility, belief } \\
\text { in the harmfulness of hormonal contraceptives, and } \\
\text { avoidance of regular gynecological examinations, as well } \\
\text { as breast examinations (Bjelica, 2018). } \\
\text { - Also, numerous deliberate breaks of pregnancy were } \\
\text { registered. }\end{array}$ \\
\hline & $\begin{array}{l}4.4 \text { What benefits are } \\
\text { expected for the target } \\
\text { group? }\end{array}$ & $\begin{array}{l}\text { - Better information and more knowledge about } \\
\text { reproductive health and certain problems from that domain } \\
\text { that could lead to the increased care about their own } \\
\text { reproductive health. }\end{array}$ \\
\hline & $\begin{array}{l}4.5 \quad \text { What costs are } \\
\text { expected? }\end{array}$ & $\begin{array}{l}\text { - Potential costs are associated with the adoption of } \\
\text { behavior characterized by increased concern for their own } \\
\text { reproductive health - costs of examinations and possible } \\
\text { therapies if they apply for a check in the private health } \\
\text { sector, as well as the price of the selected contraceptive } \\
\text { drugs/means. }\end{array}$ \\
\hline
\end{tabular}




\begin{tabular}{|c|c|c|}
\hline & $\begin{array}{l}4.6 \quad \text { What are the } \\
\text { obstacles? }\end{array}$ & $\begin{array}{l}\text { - Insufficient time for gathering information about problems } \\
\text { in the domain of reproductive health, } \\
\text { - Avoidance of gynecological examinations and breast } \\
\text { examination due to discomfort, feeling of shame, } \\
\text { - Non-use of the contraceptive means because of the belief } \\
\text { in the harmfulness of hormonal contraceptives, and also } \\
\text { disturbing the spontaneity of the sexual intercourse. }\end{array}$ \\
\hline & $\begin{array}{l}\text { 4.7 Common behavior of } \\
\text { the competition? }\end{array}$ & $\begin{array}{l}\text { - Ignoring reproductive health information, } \\
\text { - Avoiding regular visits to a gynecologist and a breast } \\
\text { specialist, } \\
\text { - Avoiding contraception. }\end{array}$ \\
\hline & $\begin{array}{l}4.8 \text { Which benefits the } \\
\text { target group could see } \\
\text { from that behavior? }\end{array}$ & $\begin{array}{l}\text { - Less time is spent on reading about certain problems in the } \\
\text { domain of reproductive health, as well as on visits to a } \\
\text { doctor, } \\
\text { - The spontaneity of sexual intercourse is not disturbed, } \\
\text { - No hormonal preparations are taken for the purpose of } \\
\text { contraception. }\end{array}$ \\
\hline & $\begin{array}{l}\text { 4.9 Which costs the target } \\
\text { group could associate to } \\
\text { that behavior? }\end{array}$ & $\begin{array}{l}\text { - If a malignant disease is not detected in a timely manner, it } \\
\text { can lead to significant costs, } \\
\text { - Cost of intervention in an unwanted pregnancy. }\end{array}$ \\
\hline \multirow[t]{3}{*}{$\begin{array}{l}5 . \\
\text { MARKETING } \\
\text { STRATEGIES }\end{array}$} & 5.1 Product & $\begin{array}{l}\text { 5.1.1 What is the core product/behavior? } \\
\text { - Better reproductive health, longer and healthier life. } \\
\text { 5.1.2 What is the actual product/desired behavior? } \\
\text { - More information and care about the own reproductive } \\
\text { health, regular visits to the gynecologist } \\
\text { 5.1.3.1 Will new tangible objects be included in the program } \\
\text { or campaign? } \\
\text { - A tangible object that is the backbone of the campaign is a } \\
\text { planned application with reproductive health information } \\
\text { that will be available for download at Google Play Store, } \\
\text { the Apple App Store. } \\
\text { 5.1.3.2 Do the existing tangible objects need to be improved? } \\
\text { - There are no similar apps on Serbian market. }\end{array}$ \\
\hline & 5.2 Price & $\begin{array}{l}\text { - The application will be free to download and use } \\
\text { - Tangible costs will reflect in the price of preventive } \\
\text { checks at the doctors if private sector is selected, price of } \\
\text { contraceptive drug/mean or method, price of treatment. } \\
\text { - Intangible costs are related to spent time, effort and energy } \\
\text { for reading information about reproductive health, going to } \\
\text { doctors; psychological risks such as the fear of a diagnosis, } \\
\text { as well as unpleasant experience of going to doctors or } \\
\text { going to checks of breast and mammography. } \\
\text { - Financial stimulations are reflected in e.g. lower cost of a } \\
\text { contraceptives for women who regularly go to preventive } \\
\text { gynecological examinations (coupons obtained at each } \\
\text { check). } \\
\text { - Potential non-monetary stimulation would be certain free } \\
\text { hours (or free day) for visiting specialist doctors, as well } \\
\text { as easier access to health services provided by doctors } \\
\text { subspecialists for certain reproductive health domains. }\end{array}$ \\
\hline & 5.3 Place & $\begin{array}{l}\text { - Organized examinations by gynecologists and radiologists } \\
\text { - Doctors available in the companies } \\
\text { - Conducting mammographic scans at the mall } \\
\text { - Distribution of free contraceptives }\end{array}$ \\
\hline
\end{tabular}




\begin{tabular}{|c|c|c|}
\hline & 5.4 Promotion & $\begin{array}{l}\text { 5.4.1 Which key messages should be disseminated to the } \\
\text { target groups? } \\
\text { - Take care of your own reproductive health } \\
\text { 5.4.2 What are your specific communication goals? } \\
\text { - The importance of reproductive health } \\
\text { - It is possible to prevent certain severe illnesses and } \\
\text { conditions via regular examinations and care of their } \\
\text { own reproductive health. } \\
\text { - Target group need to be informed about reproductive } \\
\text { health, go to a regular medical examination; refuse a } \\
\text { sexual relationship without protection. } \\
\text { 5.4.3 What benefits will be promised } \\
\text { - You can have a better life if you take care of your own } \\
\text { reproductive health. } \\
\text { 5.4.4 What will be said/done to support this promise? } \\
\text { - It is possible to prevent some frequent and severe } \\
\text { diseases related to the reproductive system and treat } \\
\text { them in time, } \\
\text { - Contraception decreases the number of unwanted } \\
\text { pregnancies, } \\
\text { - Planned pregnancies can be managed with personal, } \\
\text { career, and family achievements. } \\
\text { 5.4.5 Which communication style will be used? } \\
\text { - The promotional message of the campaign was } \\
\text { selected: Reproductive Health? Be informed, be aware! } \\
\text { React! } \\
\text { audience. } \\
\text { - Bhe message that the campaign carries out calls for } \\
\text { personal responsibility for the own reproductive health, } \\
\text { points to the importance of the woman not being } \\
\text { unaware, indicates the need for action. } \\
\text { - Recommendations related to the message for the } \\
\text { - }\end{array}$ \\
\hline & 5.5. Promotion Channels & $\begin{array}{l}\text { - TV, newspapers, and social networks (Facebook and } \\
\text { Instagram) } \\
\text { - Advertisements on TV } \\
\text { - Incorporating famous persons in campaign promotion via } \\
\text { visiting TV shows, adds in journals, and adds within social } \\
\text { networks }\end{array}$ \\
\hline $\begin{array}{l}\text { 7. MEASURE- } \\
\text { MENTS AND } \\
\text { TRACKING } \\
\text { METHODS }\end{array}$ & & $\begin{array}{l}\text { - Number of the application download; The long-term } \\
\text { indicators of the success of the campaign will be expressed } \\
\text { in one year after the end of the campaign and will be based } \\
\text { on the number of preventive examinations, consultations, } \\
\text { evaluation of the sales of certain contraceptives. }\end{array}$ \\
\hline $\begin{array}{l}8 . \\
\text { BUDGETING }\end{array}$ & & $\begin{array}{l}\text { - Campaign costs include: developing the application and } \\
\text { promotion via TV, newspapers and social network } \\
\text { - Potential funding channels: Government through particular } \\
\text { ministries, non-governmental agencies, and } \\
\text { pharmaceutical companies. }\end{array}$ \\
\hline $\begin{array}{l}9 . \\
\text { FINALIZING } \\
\text { THE PLAN }\end{array}$ & & $\begin{array}{l}\text { - I phase - dissemination of information to a broader } \\
\text { audience about importance of reproductive health through } \\
\text { brief campaign message. } \\
\text { - II phase - Informing the public about the existence of an } \\
\text { application that promotes the protection of reproductive } \\
\text { health through television, newspapers and social networks } \\
\text { - III phase - Launching the applications and promoting it via } \\
\text { different channels }\end{array}$ \\
\hline
\end{tabular}




\subsection{The role of project management}

Implementation of agile project management methods can help organizations to adjust their products and services to the users' needs. Since the success of the proposed campaign heavily relies on the adoption of the developed mobile application, it is necessary to ensure the extensive usage of the app by providing high quality user experience. Technically, the proposed app is not complex, and a smaller team could develop it in a reasonable amount of time. Agile methods are specifically suitable for smaller teams and organizations, and therefore adequate for applications such as the one proposed in this paper. In addition, it is very likely that the application will be subject to changes, according to users' needs and experiences. If the change is expected, agile methods are a better choice (Yakyma, 2016) (Kostić, 2017).

\section{CONCLUSION}

The need for improving promotion and prevention of reproductive health in Serbia is evident. This paper proposes a social marketing strategy for promotion and prevention of reproductive health using the ehealth services. The proposed campaign can be used as an example of good practice for designing similar social marketing campaigns. In order to achieve the desired goals, it is necessary to manage the campaign using appropriate project management methods. Having in mind the dynamic nature of the modern life, it is expected that an agile project management approach could be a good attitude.

\section{REFERENCES}

Alves, H., Fernandes, C., \& Raposo, M. (2016). Social Media Marketing: A Literature Review and Implications. Psychology and Marketing, 33(12), 1029-1038.

Andreasen, A. (1995). Marketing social change. San Francisco: Jossey Bass.

Bjelica, A. (2018). Strategije socijalnog marketinga $\mathrm{u}$ promociji zaštite reproduktivnog zdravlja žena putem servisa e-zdravstva, Specialist thesis,
Faculty of Organizational Scineces, University of Belgrade.

Cheng, H., Kotler, P., \& Lee, N. (2011). Social marketing for public health: An Introduction. Sudbury, Mass: Jones and Bartlett

Cumming, G., Morris, E., Simpson, P., French, T., Kahana, E., Luciano, J., \& Molik, D. (2016) The future of postreproductive health: The role of the Internet, the Web, information provision and access. Post Reproductive Health, 22 (3). ISSN 2053-3691.

Dibb, S., \& Carrigan, M. (2013). Social marketing transformed. European Journal of Marketing, 47(9), 1376 1398.

Dooley, J. A., Jones, S. C., \& Desmar, K. (2009). Strategic Social Marketing in Canada: Ten Phases to Planning and Implementing Cancer Prevention and Cancer Screening Campaigns. Social Marketing Quarterly, 15(3), 33-48.

Doug, E. (2006). How social marketing works in health care. British Medical Journal, 332(7551):1207-10

Eckrich, D. W., \& Schlesinger, W. (2011). An application of the marketing concept in health-care services planning: a case report. Journal of Management and Marketing Research. Retrieved from http://www.aabri.com/manuscripts/ 10571.pdf

European Union Agency for Fundamental Rights (2018). Handbook on European data protection law - 2018 edition. Retrieved from http://fra.europa.eu/en/publication/2018/h andbook-european-data-protection-law

Firestone, R., Rowe, C. J., Modi, S. N., \& Sievers, D. (2017). The effectiveness of social marketing in global health: a systematic review. Health Policy and Planning, 32(1), 110-124.

HPV Information Centre (2017). Statistics. Retrieved from https://hpvcentre.net/datastatistics.php

iSMA, ESMA, \& AASM (2013). Consensus Definition of Social Marketing. Retrieved from http://www.isocialmarketing.org/assets/social_marketi ng_definition.pdf 
Kostić, D. (2017). Challenges of Agile Practices Implementation in the Medical Device Software Development Methodologies, European Project Management Journal, 7(2), 36-44

Kotler, P., \& Zaltman, G. (1971). Social marketing: an approach to planned social change. Journal of Marketing, 35(3), 312.

Kotler, F., Roberto, N., \& Lee, N. (2008). Socijalni marketing. Beograd: Clio.

Ling, J. C., Franklin, B. A., Lindsteadt, J. F., \& Gearon, S. A. (1992). Social marketing: its place in public health. Annual Review of Public Health. 13, 34162.

Statistical Office of the Republic of Serbia (2017). Procenjen broj stanovnika, 2017. Retrieved from http://data.stat.gov.rs/Home/Result/18010 403? language Code $=$ sr-Latn

SAMSHA (2017). Ten steps for developing a social marketing campaigns. Retrieved from https://www.samhsa.gov/capt/tools learningresources/ developing -socialmarketing-campaign

Todorović, I. (n.d.). Prodavanje prevencije socijalni marketing kao ambalaža. Retrieved from http://www.stetoskop.info/Prodavanjeprevencije-socijalni-marketing-kaoambalaza-3217-c20-content.htm

Truong, V. D. (2014). Social marketing - a systematic review of research 19982012. Social Marketing Quarterly, 20(1), 15-34.

Government of Republic of Serbia (2017). Uredba o Nacionalnom programu očuvanja i unapređenja seksualnog i reproduktivnog zdravlja građana Republike Srbije: 120/2017-10. Dostupno na http://www.pravnoinformacionisistem.rs/SlGlasnikPortal/reg/viewAct/f9 5ceffc-0307-463f-9135-3db8a49a01d0

Yakyma, A. (2016), The Rollout: A Novel about Leadership and Building a LeanAgile Enterprise, San Bernadino, CA. 